\title{
IMPLEMENTASI METODE PEMBELAJARAN INKUIRI DALAM MENINGKATKAN HASIL BELAJAR IPS SISWA KELAS VI SD NEGERI 163087 TEBING TINGGI
}

\author{
Dasmaria Sianipar \\ Surel: dasmariaptk@gmail.com
}

\begin{abstract}
ABSTRAK
Penelitian ini bertujuan untuk meningkatkan hasil belajar siswa mata pelajaran IPS melalui metode inkuiri. Penelitian tindakan kelas ini dilaksanakan sebanyak 2 siklus dengan empat tahapan yaitu : perencanaan, pelaksanaan, observasi, refleksi. Subjek penelitian ini adalah siswa kelas VI SD N 167644 Tebing Tinggi sebanyak 33 siswa. Penelitian ini menggunakan teknik analisis dekriptif kualitatif. Hasil penelitian menunjukkan bahwa penggunaan metode inkuiri mata pelajaran IPS dapat meningkatkan hasil belajar siswa yang ditandai dengan peningkatan ketuntasan belajar siswa, yaitu siklus I (78,78 \%), siklus II $(90,90 \%)$ dan dinyatakan berhasil secara klasikal 90,90\%.
\end{abstract}

Kata Kunci : Metode Pembelajaran, Inkuiri, IPS

\section{PENDAHULUAN}

Pendidikan merupakan suatu kekuatan yang dinamis dalam kehidupan setiap individu, yang mempengaruhi perkembangan fisiknya, daya jiwanya (akal, rasa, dan kehendak), sosialnya dan moralitasnya (Dwi Siswoyo, dkk 2007:17). Pendidikan merupakan usaha sadar dalam proses pembelajaran agar peserta didik dapat mengembangkan potensi dirinya secara aktif.

Seiring dengan kemajuan zaman, pengetahuanpun juga semakin berkembang. Suatu negara bisa lebih maju jika negara tersebut memiliki sumber daya manusia yang mengetahui berbagai ilmu pengetahuan disamping teknologi yang sedang berkembang pesat sekarang ini. Ilmu Pengetahuan
Sosial (IPS) merupakan salah satu mata pelajaran yang diberikan di SD yang mengkaji seperangkat peristiwa, fakta, konsep, dan generalisasi yang berkaitan dengan isu sosial. Melalui pendidikan IPS, diharapkan para siswa dapat diarahkan untuk menjadi warga Negara Indonesia yang demokratis, dan bertanggung jawab, serta warga dunia yang cinta damai (Sapriya, 2009: 194).

IPS merupakan rumpun mata pelajaran yang dikembangkan dari beberapa disiplin ilmu-ilmu sosial seperti geografi, sejarah, psikologi sosial, sosiologi, antropologi, politik, ekonomi, dan filsafat. Tujuan dari mata pelajaran IPS di SD yakni menggambarkan sasaran akhir yang hendak dicapai oleh siswa setelah mengikuti proses dan menyelesaikan pendidikan dalam program sekolah 
dasar. Dalam Permendiknas No.22 Tahun 2006 (2008: 162) memberi penjelasan bahwa "Ilmu Pengetahuan Sosial" merupakan mata pelajaran yang mengkaji seperangkat peristiwa, fakta, konsep, dan generalisasi yang berkaitan dengan isu sosial". Melalui belajar IPS siswa mendapatkan ilmu dan pengetahuan tentang tata cara berinteraksi sosial dalam kehidupan bermasyarakat.

Selanjutnya Gross (dalam Solihatin \& Raharjo, 2007: 14) mengemukakan bahwa tujuan pendidikan IPS adalah untuk mempersiapkan siswa menjadi warga Negara yang baik dalam kehidupannya di masyarakat.

Berdasarkan Permendiknas No 22 tahun 2006 tentang Standar Isi, tujuan mata pelajaran IPS bagi peserta didik bahwa: (a) mengenal konsep-konsep yang berkaitan dengan kehidupan masyarakat dan lingkungannya. (b) memiliki kemampuan dasar untuk berfikir logis dan kritis, rasa ingin tau, inkuiri, memecahkan masalah, dan keterampilan dalam kehidupan sosial. (c) memiliki komitmen dan kesadaran terhadap nilai-nilai sosial dan kemanusiaan. (d) memiliki kemampuan berkomunikasi, bekerjasama dan berkompetensi dalam masyarakat yang majemuk, ditingkat lokal, nasional, dan global

Namun dalam kenyataannya IPS sebagai salah satu mata pelajaran di SD kurang diminati oleh siswa kelas VI SD Negeri 163087 Tebing Tinggi. Hal ini ditunjukkan dengan sikap siswa yang kurang bersemangat dalam proses pembelajaran. Siswasiswa memandang pelajaran ini sulit untuk dipelajari karena memuat begitu banyak materi ajar. Berdasarkan pengamatan khususnya dalam pembelajaran IPS di SD Negeri 163087 Tebing Tinggi, proses pembelajaran yang diterapkan guru masih berpusat pada guru yang terlihat dari pasifnya siswa selama proses pembelajaran, belum pernah diterapkan strategi pembelajaran inkuiri pada proses pembelajaran sebelumnya, kurangnya antusias siswa dalam proses pembelajaran IPS, siswa tidak berani menyatakan pendapat, dan semua berdampak pada rendahnya hasil belajar IPS siswa kelas VI SD Negeri 163087 Tebing Tinggi yang terbukti dengan masih sedikit siswa yang hasil belajar IPSnya mencapai KKM dengan persentase ketuntasan yaitu $66,67 \%$.

Salah satu upaya yang dapat dikembangkan guru adalah dengan memilih dan menerapkan strategi pembelajaran yang memberikan tantangan sekaligus menyenangkan yakni dengan menerapkan strategi pembelajaran inkuiri dalam proses pembelajaran. Menurut Sanjaya (2008:196) "Strategi pembelajaran inkuiri adalah rangkaian kegiatan pembelajaran yang menekankan pada proses berpikir secara kritis dan analitis untuk mencari dan menemukan sendiri jawaban dari suatu masalah yang dipertanyakan”. 
Metode inkuiri (scientific inquiry) metode pembelajaran yang dilakukan dengan cara menumbuhkan kemampuan berpikir, bekerja, dan bersikap ilmiah serta mengkomunikasikannya sebagai aspek penting kecakapan hidup (Hamalik, 2010:157). Siswa benarbenar ditempatkan sebagai subjek yang belajar. Peranan guru dalam pembelajaran dengan metode inkuiri adalah sebagai pembimbing dan fasilitator. Tugas guru adalah memilih masalah yang perlu disampaikan kepada kelas untuk dipecahkan. Namun dimungkinkan juga bahwa masalah yang akan dipecahkan dipilih oleh siswa dalam rangka memecahkan masalah. Bimbingan dan pengawasan guru masih diperlukan, tetapi intervensi terhadap kegiatan siswa dalam pemecahan masalah harus dikurangi (Sagala, 2004).

Menurut Sumantri M dan Johar Permana (2000:142), inkuiri adalah cara penyajian pelajaran dengan memberi kesempatan kepada peserta didik untuk menemukan informasi dengan atau tanpa bantuan guru. Metode inkuiri memungkinkan para peserta didik menemukan sendiri informasi-informasi yang diperlukan untuk mencapai tujuan belajarnya, karena metode inkuiri melibatkan peserta didik dalam proses-proses mental untuk penemuan suatu konsep berdasarkan informasi-informasi yang diberikan guru. Pada prinsipnya tujuan penerapan metode inkuiri dalam pembelajaran di kelas membantu siswa bagaimana merumuskan pertanyaan, mencari jawaban atau pemecahan untuk memuaskan keingintahuannya dan untuk membantu teori dan gagasannya tentang dunia.

Penelitian lain yang relevan juga menyebutkan bahwa inkuiri meningkatkan hasil belajar siswa. Penelitian Mukaromah (2014) menyimpulkan bahwa penerapan strategi pembelajaran inkuiri pada tema lingkungan dapat meningkatkan hasil belajar IPS siswa kelas II SD Negeri Perumnas 3 Depok Tahun Pelajaran 2012/2013. Peningkatan tersebut ditandai dengan $86,36 \%$ dari jumlah siswa memenuhi Kriteria Ketuntasan Minimal (KKM) yang telah ditentukan. Pada pra tindakan jumlah siswa yang memenuhi standar KKM ada 9 siswa, setelah dilaksanakan tindakan siklus 1 siswa yang memenuhi standar KKM menjadi 16 anak, kemudian setelah tindakan siklus 2 siswa yang memenuhi standar KKM meningkat lagi menjadi 19 anak.

Berdasarkan permasalahan tersebut maka penulis tertarik untuk meneliti metode ini karena membantu siswa bagaimana merumuskan pertanyaan, mencari jawaban atau pemecahan untuk memuaskan keingintahuannya dan untuk membantu teori dan gagasannya tentang dunia. Lebih jauh lagi dikatakan bahwa pembelajaran inkuiri bertujuan untuk 
mengembangkan tingkat berpikir dan juga keterampilan berpikir kritiskhususnya pada mata pelajaran IPS.

Berdasarkan uraian pada latar belakang masalah, maka dapat dirumuskan permasalahan sebagai berikut: "Apakah dengan menggunakan pembelajaran metodeinkuiri meningkatkan hasil belajar IPAsiswa kelas VI SD Negeri 163087 Tebing Tinggi Tahun pelajaran 2015/2016?"

Tujuan dari penelitian ini adalah untuk meningkatkan hasil belajar IPA siswa kelas VI SD Negeri 163087 Tebing Tinggi tahun pembelajaran 2015/2016 melalui metode inkuiri.

\section{METODE PENELITIAN}

Metode adalah suatu cara yang digunakan untuk memecahkan masalah penelitian. Penelitian ini menggunakan rancangan Penelitian Tindakan Kelas (PTK). Penelitian ini diawali dengan pengajuan judul tentang penelitian yang akan dilaksanakan. Subjek penelitian adalah siswa kelas VI SD Negeri 163087 Tebing Tinggi semester II tahun pelajaran 2015/ 2016 dengan jumlah siswa sebanyak 33 orang dengan 16 orang laki-laki dan 17orang perempuan. Sumber data yang digunakan adalah siswa dan teman sejawat.

Pada Penelitian tindakan kelas data yang dikumpulkan dapat berbentuk kuantitatif maupun kualitatif. Penelitian tindakan kelas tidak menggunakan uji statistik, tetapi dengan deskriptif. Data kuantitatif yang berupa nilai dianalisis dengan menggunakan analisis deskriptif komparatif yaiu membandingkan nilai tes kondisi awal, nilai tes setelah siklus I dan II yaitu nilai dari hasil ulangan harian siswa kelas VI SD Negeri 163087 pada siklus I dan II. Komponen pengajaran metode inkuiri yang sangat data kualitatif yang berupa observasi kegiatan guru, dan sisa serta data kuantitatif yang berupa nilai hasil ulangan harian siswa kelas VI.

Penelitian ini adalah penelitian tindakan kelas (PTK), yang terdiri dari 2 siklus. Sesuai dengan jenis penelitian yang dipilih, yaitu penelitian tindakan, maka penelitian ini menggunakan model penelitian tindakan dari Kemmis dan Taggart (dalam Sugiarti, 1997: 6), yaitu berbentuk spiral dari siklus yang satu ke siklus yang berikutnya.Masingmasing siklus terdiri dari dua kali pertemuan yaitu sebagai berikut:

\section{Perencanaan}

Sebelum mengadakan penelitian peneliti menyusun rumusan masalah, tujuan dan membuat rencana tindakan, termasuk di dalamnya RPP, LKS, observasi, instrumen penelitian dan perangkat pembelajaran. 
2. Pelaksanaan

a. Siklus I

Siklus I dilakukan pada tanggal 3 Maret 2016. Penerapan inkuiri dilakukan dengan Kegiatan awal melakukan apersepsi, memberikan motivasi dan pengarahan tentang topik yang akan dipelajari. Kegiatan inti yaitu guru memberikanpenjelasan untuk pengantar pengamatan mengenai materi ajar. Guru langkah-langkah metode pembelajaran. Menjelaskan materi terkait dengan metode inquiri. Merumuskan masalah mengenai materi pembelajaran metode inquiri. Mengawasi dan memberikan bantuan kepada siswa yang mengalami kesulitan.Pada kegiatan akhir guru memberikan kesimpulan dan melakukan tes evaluasi.

\section{b. Siklus II}

Siklus II dilakukan pada tanggal 10 Maret 2016. Siklus II hampir sama dengan siklus I hanya saja pada siklus II ada perbaikan ke arah yang lebih baik. Tindakan pada siklus II ini dilakukan dengan menggunakan paduan perencanaan dan dalam pelaksanaannya bersifat fleksibel serta terbuka terhadap perubahan-perubahan. Guru mengajar dengan menggunakan RPP yang telah disusun dan dipersiapkan sebelumnya. Sedangkan, peneliti dengan bantuan teman mengamati pelaksanaan tindakan dengan menggunakan lembar observasi yang telah dipersiapkan sebelumnya.
Kegiatan yang dilakukan pada tahapan inisama dengan siklus II yaitu terdiri dari kegiatan awal, kegiatan inti dan kegiatan penutup.

\section{Pengamatan}

Pengamatan dalam proses kegiatan pembelajaran menggunakan metode inkuiri dilakukan oleh peneliti. Kegiatan tersebut dilakukan untuk mengumpulkan data-data yang akan diolah untuk menentukan tindakan yang akan dilaksanakan peneliti selanjutnya. Observasi adalah suatu cara untuk memperoleh data dengan jalan mengadakan pengamatan langsung secara sistematis terhadap suatu objek tertentu yang dicatat dalam catatan observasi (lembar observasi). Pengamatan yang dimaksud adalah pengamatan dengan seluruh alat indera (Arikunto, 1998:128). Pada akhir siklus, peneliti melakukan evaluasi kepada siswa dengan melakukan tes evaluasi.

\section{d. Refleksi}

Peneliti mengkaji, melihat dan mempertimbangkan hasil atau dampak dari tindakan yang dilakukan berdasarkan lembar pengamatan yang diisi oleh pengamat. Tahapan ini dilakukan secara berkesimbungan sehingga ditemukan hasil yang optimal. Kegiatan pada tahap refleksi meliputi kegiatan menganalisis, memahami dan membuat kesimpulan berdasarkan hasil observasi setiap siklus. Menemukan kelebihan dan 
kelemahan tindakan perbaikan pembelajaran. Hasil analisis data yang dilaksanakan pada tahap ini akan dipergunakan untuk menemukan kelebihan dan kelemahan diri dalam merancang dan melakukan tindakan sebagai acuan.

Metode pengumpulan data penelitian ini adalah tertulis dan observasi. Penelitian ini dikatakan berhasil apabila siswa telah memperoleh nilai ketuntasan secara klasika lminimal $85 \%$ dari jumlah siswa dengan rumus sebagai berikut :

Persentase Ketuntasan klasikal =

Jumlah siswa yang tuntas $\times 100 \%$

Jumlah siswa yang mengikuti tes

\section{HASIL DAN PEMBAHASAN}

Berdasakan refleksi awal dapat diketahui bahwa dalam pelaksanaan pembelajaran di kelas, penulis menemukan beberapa permasalahan. Permasalahan tersebut antara lain rendahnya keaktifan siswa dalam mengikuti proses pembelajaran di kelas.

Hasil penelitian tindakan
kelas menunjukkan bahwa
pengamatan yang dilakukan oleh
peneliti dan mitra kolaborasi terhadap
hasil belajar IPS metode inkuiri di
kelas VI SD Negeri 163087 Tebing
Tinggi dapat dilihat pada Tabel 1
yaitu sebagai berikut:

Hasil penelitian tindakan a 
kegiatan guru saat dikelas. Keterampilan guru yang tampak dalam mempersiapkan pembelajaran dan menciptakan kesiapan mental dan menarik perhatian peserta didik secara optimal agar terpusat sepenuhnya untuk belajar.

Pembelajaran sebagai proses interaksi berarti menempatkan guru bukan sebagai sumber belajar, tetapi sebagai pengatur interaksi itu sendiri. Kegiatan pembelajaran selama menggunakan pendekatan inkuiri ditentukan oleh interaksi siswa. Keseluruhan proses pembelajaran akan membantu siswa menjadi mandiri, percaya diri dan yakin pada kemampuan intelektualnya sendiri untuk terlibat secara aktif. Guru hanya perlu menjadi fasilitator dan mengarahkan agar siswa bisa mengembangkan kemampuan berpikirnya melalui interaksi mereka. Guru juga harus memfokuskan pada tujuan pembelajaran, yaitu mengembangkan tingkat berpikir yang lebih tinggi dan keterampilan berpikir kritis siswa.

Pembelajaran IPS dengan menggunakan metode inquiri dapat mengembangkan kemampuan berpikir, karena inkuiri didasari oleh teori kognitif yang menekankan arti penting proses internal seseorang. Hal ini sesuai dengan pendapat Hamalik (2010:157), metode inkuiri (scientific inquiry) metode pembelajaran yang dilakukan dengan cara menumbuhkan kemampuan berpikir, bekerja dan bersikap ilmiah serta mengkomunikasikannya sebagai aspek penting kecakapan hidup. Pembelajaran IPS terpadu dengan metode inquiri dapat menimbulkan respon positif pada diri siswa sehingga siswa tidak merasa bosan selama proses pembelajaran.

Selain itu peran guru juga mempengaruhi hasil belajar siswa.Seorang guru seharusnya mampu merangsang daya pikir dan kreatifitas peserta didik dalam menemukan informasi.Guru harus mampu menciptakan suatu lingkungan belajar yang kondusif dan memahami kesulitan yang dihadapi siswa ketika pembelajaran berlangsung. Guru harus menghindari penyajian informasi dalam bentuk ceramah karena hal ini akan mengakibatkan kurangnya partisipasi siswa dalam kegiatan pembelajaran untuk memenuhi salah satu karakteristik model yang diharapkan.

Hasil tersebut dapat dilihat dari nilai ulangan harian yang diperoleh siswa. Nilai rata-rata kelas pembelajaran siklus I menunjukkan peningkatan bila dibanding dengan pra tindakan, yaitu dari 22 siswa $(66,67 \%)$ yang tuntas belajar menjadi 26 siswa $(78,78 \%)$ pada siklus I kemudian pada siklus II meningkat menjadi 30 siswa yang tuntas (90,90\%). Penerapan metode inquiri dapat meningkatkan hasil belajar siswa karena metode ini membimbing siswa dalam menemukan konsep materi pertumbuhan dan perkembangan makhluk hidup, 
melalui kegiatan pengamatan dan pertanyaan-pertanyaan sehingga siswa mampu menemukan konsepnya sendiri. Inkuiri adalah mengajukan pertanyaan-pertanyaan, yaitu pertanyaan-pertanyaan yang dapat dijawab dan mengantarkan pada pengujian dan eksplorasi bermakna. Selama pembelajaran inkuiri, guru dapat mengajukan suatu pertanyaan atau mendorong siswa mengajukan pertanyaan-pertanyaan mereka sendiri, yang dapat bersifat openended, memberi peluang siswa untuk mengarahkan penyelidikan mereka sendiri dan menemukan jawabanjawaban.

Berdasarkan hasil pengamatan guru selama melakukan pembelajaran pada siklus I maka dilakukan perbaikan pada siklus II. Tindakan siklus II dilaksanakan, hasil siklus II terlihat terjadi peningkatan jika dibandingkan dengan hasil yang diperoleh pada siklus I. Pada siklus II guru telah mengelola kelas dengan baik sehingga terjadi peningkatan aspek-aspek kegiatan dari siklus sebelumnya. Peningkatan itu dapat terlihat pada proses dan hasil pembelajaran. Aktivitas siswa pada siklus II mengalami peningkatan. Secara garis besar kegiatan belajar mengajar dengan metode pembelajaran inquiri dilaksanakan terjadi peningkatan ke dalam kategori baik.

Proses kegiatan belajar mengajar yang dilakukan guru lebih baik setiap siklusnya seperti guru sudah bisa menguasai kelas, namun masih ada beberapa aspek yang belum bisa dilaksanakan yaitu mengaitkan materi dengan pengetahuan lain yang relevan, mengaitkan materi dengan realitas kehidupan, dan melaksanakan pembelajaran sesuai dengan alokasi waktu. Tetapi secara keseluruhan menunjukkan bahwa proses belajar mengajar berlangsung secara lancar, kondusif, dan tujuan pembelajaran tercapai.

Dari hasil tes siklus I dan II dapat dilihat bahwa hasil belajar dengan menggunakan metode pembelajaran inkuiri telah mampu meningkatkan pemahaman siswa mengenai materi pelajaran IPS sesuai dengan indikator yang telah ditentukan sehingga tidak perlu lagi dilanjutkan pada siklus berikutnya dan dikatakan berhasil. Menurut Sumantri M dan Johar Permana (2000:142), inkuiri adalah cara penyajian pelajaran dengan memberi kesempatan kepada peserta didik untuk menemukan informasi dengan atau tanpa bantuan guru. Metode inkuiri memungkinkan para peserta didik menemukan sendiri informasiinformasi yang diperlukan untuk mencapai tujuan belajarnya, karena metode inkuiri melibatkan peserta didik dalam proses-proses mental untuk penemuan suatu konsep berdasarkan informasi-informasi yang diberikan guru

$$
\text { Gambaran peningkatan }
$$

ketuntasan belajar yang diperoleh 
setelah melakukan penelitian dengan menggunakan metode inkuiri terlihat pada diagram berikut:

\section{Diagram 1. Peningkatan}

Ketuntasan Belajar

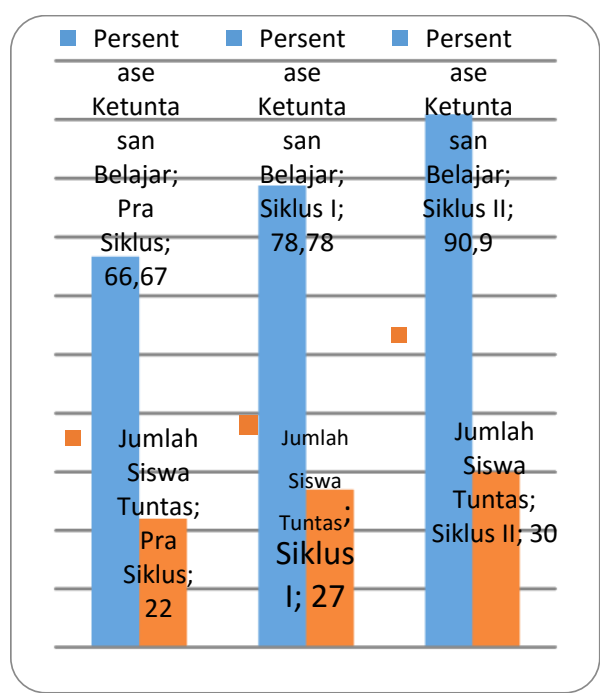

Dengan melihat indikator yangt telah ditetapkan sebelumnya, hasil yang diperoleh telah mencapai lebih dari batas minimal indikator keberhasilan sehingga penelitian tidak perlu dilanjutkan lagi untuk siklus berikutnya. Oleh karena itu dapat disimpulkan bahwa proses pembelajaran dengan penerapan penemuan terbimbing sangat sesuai dengan mata pelajaran IPS, maka Penelitian Tindakan Kelas (PTK) ini bisa dikatakan berhasil karena hasil peningkatan proses pembelajarannya optimal.

\section{SIMPULAN}

Dari hasil temuan penelitian tentanghasil belajar siswa dengan metode penemuan terbimbing di kelas VI SD Negeri 163087 Tebing
Tinggi tahun pelajaran 2015/2016 berdampak positif dalam meningkatkan keterampilan guru dan hasil belajar siswa setiap siklusnya. Penerapan strategi pembelajaran inkuiri pada tema lingkungan sudah menunjukkan adanya kemauan dan kemampuan serta aktivitas siswa dalam merumuskan masalah, menentukan hipotesis, membuat siswa berani bertanya, menjawab, dan mengajukan gagasan. Selain itu juga telah mengaktifkan siswa dalam proses diskusi. Hal tersebut dapat dilihat dari peningkatan persentase ketuntasan belajar siswa pada siklus I $(78,78 \%)$, siklus II $(90,90 \%)$ dan dinyatakan berhasil.

Atas dasar simpulan dan implikasi hasil penelitian tindakan kelas di atas, penulis memberikan saran-saran sebagai berikut :

1. Bagi Sekolah

Sebaiknya menyediakan sarana yang dapat mendukung kegiatan belajar mengajar dan pelatihan terhadap penelitipeneliti kelas mengenai metode pembelajaran khususnya metode inquiri.

2. Bagi Guru

Guru dapat berinovasi dengan memberikan sistem belajar yang menarik, buatlah inovasi dan tingkatkan kreatifitas dalam PBM serta berusaha untuk selalu meningkatkan dan memperbaiki pembelajara guna mewujudkan cita-cita bangsa. 
3. Bagi Siswa

Harus terlibat secara aktif dalam proses belajar mengajar, hal ini akan mempermudah tercapainya tujuan belajar.siswa harus saling menghormati dan menghargai pendapat teman, beranikan diri untuk bertanya maupun berpendapat. Selain itu, tingkatkan semangat belajar agar hasil belajar meningkat.

\section{DAFTAR RUJUKAN}

Dwi Siswoyo, dkk. 2007. Ilmu Pendidikan. Yogyakarta: UNY Press.

Mukaromah, M. A. 2014. Penerapan Strategi Pembelajaran Inkuiri Pada Tema Lingkungan Untuk Meningkatkan Hasil Belajar IPS Siswa Kelas VI SD Negeri Perumnas 3 Depok Tahun Pelajaran 2012/2013. Skripsi: Universitas Negeri Yogyakarta.

Sagala. 2004. Konsep dan Makna Pembelajaran. Bandung: Penerbit Alfabeta.

Sanjaya, W. 2008. Strategi Pembelajaran Berorientasi Standar Proses Pendidikan. Jakarta: Kencana Prenada Media.

Sapriya. 2009. Pendidikan IPS. Bandung: Remaja Rosdakarya.
Solihatin, E. dan Raharjo. 2007. Cooperative Learning. Jakarta: Bumi Aksara.

Sumantri, M., dan Johar Permana. 2000. Strategi Belajar Mengajar. Jakarta: Dirjen Dikti Depdikbud. 